\title{
Causality Relationships between Main Branding Variables and International Marketing Strategy: Evidence from MNCs in GCC Market
}

\author{
Mansour S. M. Lotayif ${ }^{1}$ \\ ${ }^{1}$ Faculty of Commerce, Beni,Suef University, Egypt \\ Correspondence: Mansour S. M. Lotayif, Faculty of Commerce, Beni,Suef University, Egypt. E-mail: \\ Mansourlotayif@hotmail.com
}

Received: October 1, 2016

Accepted: November 20, $2016 \quad$ Online Published: December 28, 2016

doi:10.5539/ijbm.v12n1p140

URL: http://dx.doi.org/10.5539/ijbm.v12n1p140

\begin{abstract}
This research designed to figure out the sets of variables needed for designing an international marketing strategy (IMS) in GCC context. Therefore, the causality relationships between designing an IMS and brand orientation (BO), brand performance (BP), international financial performance (FP), international commitment (ICOM), brand repositioning (BR), congruence of marketing environment (CUE), controlling international branding activities (CIBA), and demographic factors (DF) were tested. The experiences of 156 senior executives, with international experience, working in GCC market have been utilized for that purpose. Via SPSS version twenty one and throughout multi-variant e.g. multiple regression, bi-variant e.g. correlation, and uni-variant e.g. descriptive analytical techniques, the research eight aims and hypotheses were tested. The study revealed that there are significant causality relationships between designing international marketing strategy (IMS) and study's demographics, brand orientation, financial performance, brand performance, international commitment, brand repositioning, congruence of marketing environment, and control of international branding activities. In branding context in GCC, the current study is a pioneer endeavor in this perspective. Research findings were seen as a pioneer endeavor outside the USA companies and markets that attracted most of international marketing scholars.
\end{abstract}

Keywords: branding, international marketing strategy (IMS), and Gulf Cooperation Council GCC (Bahrain, Qatar, UAE, KSA, Kuwait and Oman)

\section{Introduction}

Nowadays, it is argued that effective international marketing activities are crucial for those ambitious businesses working in highly competitive markets with diversified culture backgrounds. These cultural diversities have serious ramifications on consumer behaviors at large (Czinkota \& Ronkainen, 2007; Calderon et al., 1997; Mosmans, 1996; Rubinstein, 1996; Farquhar, 1994; Biel, 1992; Marus \& Kitayama, 1991). Literally, marketing activities are those needed to transfer the perceived value to customers in their particular markets. These activities have been extracted from what so called 4P's components i.e. marketing mix (e.g. product, price, place, promotion) in case of commodities marketing and 7P's (adding up three more components: physical, process, and personnel) in case of marketing the intangibles. Also, these marketing activities are extracted from the traditional promotional mix components (advertising, personal selling, publicity, and sales promotion). But amongst these marketing activities, branding decisions and activities have taken higher ranking for both domestic and international marketing. More specifically, Calderon et al., 1997; Mosmans, 1996; Rubinstein, 1996; Farquhar, 1994; Biel, 1992 have argued about the perception of brand strategy as a main source of firms' competitive edge in their home marketplace. Wernerfelt (1984) explicitly stressed the practical importance of brand name as invisible asset and its ramifications on generating excess revenues in international markets. The revision of mainstream marketing journals has revealed shortages in covering the international marketing topics overseas. Therefore and in general, compared to domestic marketing topics, international marketing activities and issues have received less focus as presented in the mainstream marketing journals as argued by Wong and Merrilees (2007); Douglas and Craig, (1992), and Albaum and Peterson, (1984). Moreover and in particular, there is less focus on global branding researches and activities are presented in the mainstream marketing journals (Wong \& Merrilees, 2007). Also, Varadarajan and Jayachandran (1999) did criticized marketing 
strategy's literature in this perspective (i.e. less focus is given to foreign markets), as the vast majority of branding researches were conducted on US firms. Consequently, there is an obvious literature's gap in this perspective that needs to be filled appropriately by seeking for applications, getting more evidences, and generalizing the current international marketing modes in different global markets with diversified culture backgrounds. Consequently, this research is an endeavor in filling part of the current literature's gap by figuring out the main branding variables behind designing and redesigning of international marketing strategy with empirical evidences from GCC markets (i.e. Bahrain, Qatar, UAE, KSA, Kuwait and Oman).

\section{Literature Review}

At the beginning it is worth shedding light on brand name as a marketing jargon. A brand name is the comprehensive and invisible variable that has impacts on all firm's marketing activities by creating an image (preferably to be positive image) in consumer/customer's mind that leads to strengthening the success via creating excessive revenues and enhancing the market value in the long run. Therefore good brand name has a strong strategic role in the long run with positive ramifications on performance (Mosmans \& Van der Vorst, 1998; Mosmans, 1996; Yovovich, 1988). Also it works as a strategic reference point in comparing between commodities and services (Wong \& Merrilees, 2007). Therefore, the selection of band name's words and logo should be done professionally to be perceived as "culture friendly". To guarantee appropriate and profitable level of market penetration across global markets, the design of firm's logo, words, colors, and shape should not challenge each and every culture worldwide. For instance, there is common perception for "lion" as a symbol of power and courage. In some communities, especially those living nearby jungles and daily observing its behavior, it is considered as a lazy animal that hunt to eat and then sleep. In this perspective, Marc et al. (2015) argued that shorter brand names, and those with semantic relevance to English language are perceived more and are more memorable by customers. Also, the pronounceability of the brand name has strong impacts on brand name preference in terms of its meaningfulness, memorability and likeability. Therefore, if such markets are important and classified as target markets, avoiding such logos that challenge the local cultures could be essential. For the above logic, international cultures should be considered whenever designing the logos and selecting the brand names.

The comprehensive revision of the literature of international branding revealed that scholars have been focused their efforts on few topics such as: (1) brand name standardization versus adaptation (e.g. Erdem et al., 2006; Alashban et al., 2002; Francis et al., 2002; Dong and Marilyn, 2001; Zou et al., 1997; and Sandler and Shani, 1992); (2) cultures ramifications on branding and repositioning. In this stream of literature culture could be perceived as software of minds that represent a collective programming for each culture group. And its consequences on values, beliefs, norms, and behavioral patterns, that help in distinguishing each market, ought to be considered whenever selecting and designing branding strategies that fits each market (e.g. Yaprak, 2008; Leung et al., 2005; House et al., 2004; Bond et al., 2004; Hofstede, 2001; Chapman, 1997; D’Iribarne, 1997; Schwartz \& Bilsky, 1990; Levine, 1984; Hofstede, 1980, and 1983; Rokeach, 1973; Hall, 1970; Lee, 1966; Hall, 1960). (3) globalised marketing and branding activities (e.g. Rugman, 2001a,b; O’Donnell and Jeong, 2000; Zou and Cavusgil, 1996; Agrawal, 1995; Kotler, 1986; Levitt, 1983); (4) "think global act local" marketers (e.g. Rugman, 2001a; Sandler and Shani, 1992; Will and Jacobs, 1991); and (5) brand repositioning (e.g. Merrilees, 2007; Wong and Merrilees, 2006; Cheng et al., 2005; Hsieh and Lindridge, 2005; Czinkota et al., 2001; and Ganesh \& Oakenfull, 1999). The current study adopts a bit comprehensive approach by considering the local culture of GCC markets, in designing the international branding strategy, with much focus on Wong and Merrilees' methodology (2007).

Wong and Merrilees, (2007); Wong and Merrilees, (2006); and Czinkota et al., (2001) claimed that brand repositioning (PR) is entirely different from marketing mix adaptation (MMA) as PR touches the psychological and cultural aspects and broader view from creation to the placement of that brand in customer minds. However, MMA that uses the 4P's concept is concerning only about changing package's physical aspects e.g. brand name, colors, packaging, ways of distribution, ways of advertising etc. In international marketing context, Hsieh and Lindridge, (2005); and Cheng et al. (2005), for instance, have tested the brand image relationships with customer's attitudes and behaviors in a cross cultural setting and they found that consumer's sensory, utilitarian, symbolic and economic needs are different across these different countries. In this perspective specifically, they found Taiwanese and Korean industrials' brands have been evolved through four major stages e.g. namely pre-international, lead market carrying capacity, international branding and market succession, and local climax.

For firm's performance in international marketing literature, the firm external environment and culture determine its performance (Caves, 1972). These environmental variables include physical, social, cultural and technological variables (Lotayif, 2016, Preble et al., 1988; and Subramanian et al., 1993). Wernerfelt (1984) argued about the 
possibility of making brand name as an intangible asset and main resource that yield high revenues in the long run, especially in foreign markets.

In this perspective, Leonidas et al., (2010) have done a comprehensive survey of 508 international marketing-focused articles published at the period from 1975 to 2004 in top ten mainstream marketing journals. Each article was content-analyzed in terms of six main pillars; article nature, authorship characteristics, study design, scope of study, study methodology, and thematic areas. They did find the area of branding-performance relationships in international marketing context still in its beginning stage and need to be deeply and comprehensively addressed to fill part of the existed literature's gap. Also, Malhotra et al. (1999) claimed that there is a strong need to fill the literature's gap on well understanding the strategic role a brand could play in enhancing the financial position of any company both domestically and internationally. Therefore, the need to get applications and evidences from other foreign markets, rather than the US mark, was pinpointed here. Moreover, Wong and Merrilees (2007) invited other scholars for more exploration in this area of research for the sake of generalizability of the model by applying their branding model in other areas and markets. They claimed that there is a lack of brand studies in the international context, as literature has covered a wide range of topics from management of a brand name to the strategic use of a brand name in domestic context only not international one. Therefore, following the model suggested by Wong, and Merrilees (2007), the current study examines that model in a GCC context to get compelling evidences from other markets rather than US one. The model relationships' network is presented in Figure 1.

With reference to "resource-based concept", any organization could be viewed as a set of capabilities and resources that include physical and intangible assets. Having said that, brand name and its ramifications on performance is considered an asset that enhances the firm's capabilities. And an organization could create a competitive advantage by well deploying and utilizing of its main resources and capabilities (Peteraf, 1993; Grant, 1991). However, sometimes in some markets, the firm's resources and capabilities alone may not be able to fully explain firm's performance. In such cases, the invisible effects of brand performance could be responsible. Therefore, the created competitive advantage via brand performance coupled with the perceived value created by other firm's resources and capabilities will help enhance the comprehensive image and sustain the existed competitive advantages. To sum up, nothing positive could happen in firms' performances without strong harmony and homogeneity with the external environments and cultures. (Black and Boal, 1994).

As shown in Figure (1), the model components are international marketing strategy (IMS), brand orientation (BO), overall international financial performance (FP), international commitment (ICOM), brand repositioning (BR), congruence i.e. similarity of marketing environment (CUE), control of international branding activities (CIBA) (Wong and Merrilees, 2007), and demographic factors (DF) is added in the current study (Lotayif, 2015b) . First, international marketing strategy includes the four Ps of the marketing mix (i.e. product, price, promotion, and place), which reflects marketing concept' fundamentals and the variables related to branding strategy (Appiah-Adu, 1997). Paliwoda, (1999) argued that few dimensions like social, legal, economic, political or technological nature to be considered when designing the international strategy. Having said that, serving foreign markets is not an easy task, especially serving more than one market simultaneously, that needs more efforts in collecting, sorting, and analyzing markets' data to get the customer satisfaction in these diversified markets. For instance, to get the status quo in foreign markets, Japanese marketing strategy evolved via five stages: premarketing; marketing awareness and interest; marketing acceptance; marketing expansion; and global marketing (Lazer et al., 1985). To guarantee the leadership in particular foreign markets, Japanese adopted what so called "zero feedback time" and "zero improvement time" to get the needed data in real time basis and improve their products/services in a nonstop and continuous basis too (Kotler et al., 1985).

Second, brand orientation (BO) means "state of mind process" to establish a foundation for the deployment of a firm's international marketing activities (Urde, 1994, and 1999). BO is the firm's ideology that, later on, translated into actions and activities for market coverage. Inevitably, these international marketing activities differ from market to market based on the prevailed culture. However, most of the global markets are viewed as a "global village" especially after the appearance of "globalization" jargon that leads to increase the frequency and density of connection and interaction amongst nations which promote for more compatibility and consistency in firms' internal policies and business guidelines (Czinkota, 2002). Therefore, most of the multinational corporations (MNCs) serving these diversified marketplaces could use acquisitions, (full or partial) merges, joint ventures, franchising, licensing, and alliances as viable and appropriate entry modes (Lotayif, 2004, 2005, pp. 176-180). Terpstra (2000) argued about the future's trend marketplaces are following right now and the foreseeable future. That trend in world markets seems to be a case of "global oligopoly" with fewer but larger competitors facing each other in the global marketplace each of which aims at strengthening his own completive 
advantages and trying, as much as he could, to nullifying the rivals' ones. Right now for instance, in mobile phone manufacturing industry there are two main giants i.e. Apple and Samsung the same practice could be existed in other industries like car, networks, banks, food etc. Consequently, brand orientation could be viewed as a prerequisite or one of the antecedents of brand engagement as it is paving the way for that deeper marketing activity called "brand engagement" (Merrilees, 2015).

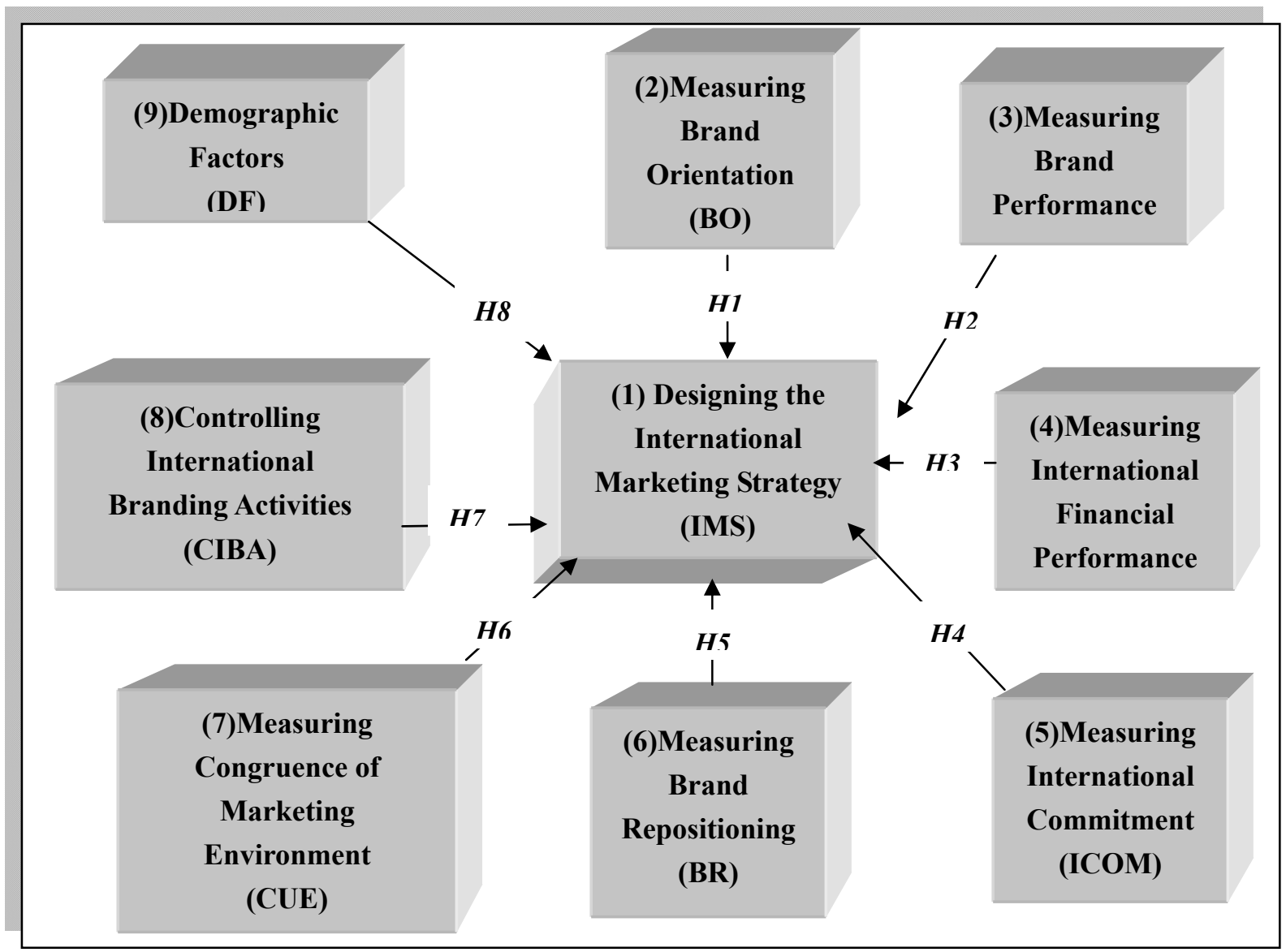

Figure 1. Conceptual framework of the current study's variables

Source: Adapted from Wong and Merrilees (2007).

Third, international marketing performance means the extent to which an organization's economic and strategic objectives (e.g. marketing a product/service in foreign markets) are achieved through planning and execution of its international marketing strategy (Wong and Merrilees, 2007). In performance's literature, the most common and viable ways of measuring performance of a profit oriented business unit could be revenue, profit, market share, and customer satisfaction. Again, culture impacts ought to be stressed here when it comes to international performance context. Home-host culture's alignment, homogeneity, and synergy are crucial in this regard. Alternatively, considering the culture differences is essential whenever taking the entry-mode decision (Lotayif, 2004, 2005). Inevitably, the failure in considering that culture's differences amongst nations might lead to businesses' failure (Ricks, 1993). In a very recent Chinese's study with 2151 valid questionnaire responses via Google and Baidu, Deli Yang et al., (2015) have been found that brand performance is affected by the power of triple contexts i.e. country, industry, and firm either directly or indirectly. Following the footsteps of Wong and Merrilees' study (2007); two dimensions will be used in measuring the performance i.e. financial and brand. Brand performance represents the success of a brand within the market and measured by customer awareness, satisfaction and loyalty (Reid, 2002, and Chaudhuri and Holbrook, 2001). Generally, financial performance is measured via the changes in profit, market share, sales, and revenues. Therefore, in the current research financial performance is measured by growth rate, market share, profitability, return on investment (ROI), ratio of overseas to domestic sales, and sales profitability ratio from the overseas market (Wong and Merrilees, 2007), as presented in Appendix (A). 
Forth, international commitment represents the extent to which resources e.g. financial, technology, information, and human resources, are made available for marketers to conduct international marketing activities (Wong and Merrilees, 2007; Silcoff, 2000; and Evangelista, 1994). On the top of these pledged resources to foreign markets and their operations, top management commitment is crucial. As without that high-level of commitment, nothing might not achieve. To measure international commitment, the current research adopted the five items used by Mavondo and Rodrigo (2001) and Cavusgil and Zou (1994), as presented in Appendix (A).

Fifth, brand repositioning is the process of adaptation of domestic brand market's position in the minds of customers in each foreign market. The purpose of that process is to be compatible with these overseas market situations (Wong and Merrilees, 2007). That means using the same competitive advantages, which have been successfully used domestically, abroad. To enhance the level of compatibility, firms ought to conduct "macro-marketing environmental scanning" studies. These studies aims at collecting, sorting, and analyzing accurate, precise, and timely data (e.g. economical, cultural, demographical, social, political, legislative etc) before taking the entry decision (Lotayif, 2004; and Ganesh and Oakenfull, 1999). Sixth, congruence of marketing environment means the similarities between domestic and international markets in which an international marketer operates (Wong and Merrilees, 2007). In this line of logic, Subramanian et al., (1993); and Preble et al., (1988) grouped these comparison factors as economic, sociocultural, and technological. The same practice has been adopted in the current research. Seventh, control of international branding activities means the use of controls as authority over operational and strategic decision-making employed by international marketers to guide inter- and intra-firms activities (Wong and Merrilees, 2007, Driscoll and Paliwoda 1997). Finally, demographic factors include types of activity, ownership styles, company's experience, and its size.

\section{Research Aims}

\subsection{The Research Objectives Could Be Summarized As Follows}

Examining and exploring the relationships of Wong, and Merrilees's model in GCC context i.e. Bahrain, Qatar, UAE, KSA, Kuwait, and Oman. Therefore, the current study aims at examining the relationships between the designing of international marketing strategy (IMS) and:

1- Brand orientation (BO);

2- $\quad$ Brand performance (BP);

3- International financial Performance (FP);

4- International commitment (ICOM);

5- Brand repositioning (BR);

6- Congruence of marketing environment (CUE);

7- Controlling international branding activities (CIBA); and

8- Demographic factors (DF).

\subsection{Study Hypotheses}

To achieve research objectives, the underneath relationships will be tested.

H1: There is a causality relationship between "designing the international marketing strategy (IMS) and brand orientation.

H2: There is a causality relationship between "designing the international marketing strategy (IMS) and brand performance.

H3: There is a causality relationship between "designing the international marketing strategy (IMS) and international marketing performance (measured via financial performance).

H4: There is a causalityrelationship between "designing the international marketing strategy (IMS) and international commitment.

H5: There is a causality relationship between "designing the international marketing strategy (IMS) and brand repositioning.

H6: There is a causality relationship between designing the international marketing strategy (IMS) and congruence of marketing environment.

H7: There is a causality relationship between designing the international marketing strategy (IMS) and control of international branding activities. 
H8: There is a causality relationship between "designing the international marketing strategy (IMS)" and study's demographics i.e. type of business, type of ownership, business experience, and business size.

\subsection{Research Methodological Steps}

In this section of the study, the study's paradigm, sample and population concepts, schemes deployed for data collection, package, ways and techniques of statistical analyses will be addressed appropriately. For research paradigm, positivistic approach through using a structured emailed questionnaire was adopted via sending each respondent a hyper-link of the study's questionnaire. The GCC business database and Arabian businesses' linkswere utilized to figure out the largest 50 businesses, as presented in Table (1). The participants or respondents were senior managers responsible for or involved in international decisions in the last three years, as clearly mentioned in the cover letter sent to each response base. International experience was stressed as a prerequisite for eligibility to answer the questionnaire otherwise to be diverted to the qualified colleague. The selected companies or "qualified firms" are those having separate local and international operations. The online organizational structure was utilized to assure this point. For sample, a convenience sample of 156 senior managers working in GCC market has been utilized in the current research. For data collection tool, an eight concept structured questionnaire with Lickert five-point scale was utilized, as shown in Appendix (A). After the cover letter that explain the study aims and eligible respondent, the questionnaire starts by four demographical variables e.g. business activity, type of ownership, business experience, and business size. The questionnaire's eight concepts are international marketing strategies designing (IMS) (from IMS1 to IMS13 and averaged to be used as a dependent variable (DV) in multiple regression), brand orientation (BO) (from $\mathrm{BO} 1$ to $\mathrm{BO}$ 6), financial performance (FP) (from FP1 to FP9), brand performance (BP) (from BP1 to BP5), international commitment (ICOM) (from ICOM1 to ICOM5), brand repositioning (BR) (from BR1 to BR6), congruence of marketing environment (CUE) (from CUE1 to CUE11), and control of international branding activities (CIBA) (from CIBA1 to CIBA3).

Table 1 . The biggest fifty gulf companies

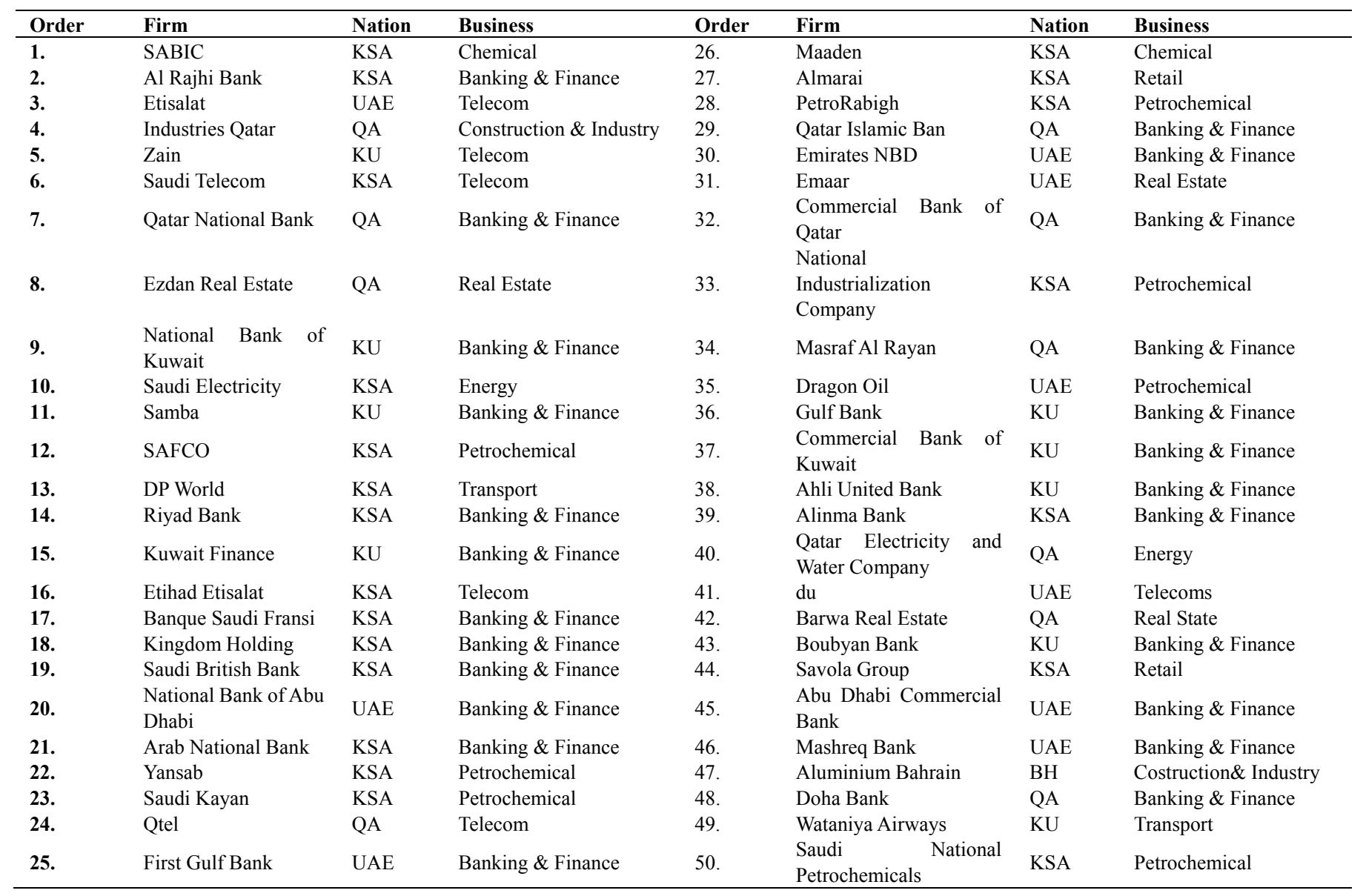

Source:Arabian Business.com. 
The response rate was 31.2 percent, as the filled and received questionnaires were 156 out of 500 . Via their emails, those 500 senior managers, marketing executives, and GMs in the biggest 50 Gulf companies were targeted and were given another reminding messages after one month. In this perspective, it worth mentioning that this response rate is acceptable compared with what have been obtained in other industrial mail surveys. For instance, Hart (1987) reported 10 percent response rate in his own mailed study. Also, Shoham (2014) interviewed only 26 response bases in similar study aims at exploring international marketing activities in foreign markets. For the deployed statistical package, SPSS release 21 was used in this perspective. Uni-variant i.e. descriptive analysis, bi-variant i.e. correlation, and multi-variant analysis (e.g. multiple regression) were used as analytical techniques in the current research.

\section{Study Results}

In this section, normality, multi-collinearity, validity, reliability, hypotheses testing, discussions, and conclusion will be addressed.

\subsection{Normality, RegressorsMulti-Collinearity, Scale Validity, and Reliability}

Statisticians revealed that data distribution's shape could be considered normal whenever the sample size is bigger than 30 cases (e.g. Ortuzar and Willumsen, 1994). Therefore, normality condition is assumed, as sample's size is 156 respondents in the current research. Also, Reliability dimension is met as Cronbach alpha coefficients reported values more than 0.60 with all concepts (e.g. Lotayif, 2016; Francis, 2001, and andRobinson et al., 1991). As in Table (2), Cronbach values are 82.5, 92.7, 80.6, 60.9, 60.4, 81.8, 98, 89.7, and 82.5 percent for the whole questionnaire (apart from demographics) and for each concept i.e. international marketing strategy, brand orientation, financial performance, brand performance, international commitment, brand repositioning, congruence of marketing environment, and control of international branding activities respectively. Therefore, reliability dimension in the current research is supported. Multi-collinearity amongst study's eight regressors is supported, as all correlations' values are less than unity, as shown in Tables (3-9).

Table 2. Research reliability values

\begin{tabular}{|c|c|c|c|c|}
\hline \multicolumn{2}{|c|}{ Items } & \multirow{2}{*}{$\begin{array}{l}\text { Respondents } \\
156\end{array}$} & \multirow{2}{*}{$\frac{\text { No. of Items }}{58}$} & \multirow{2}{*}{$\begin{array}{l}\text { Cronbach } \\
\mathbf{0 . 8 2 5}\end{array}$} \\
\hline - & The Whole Instrument's Concepts & & & \\
\hline 1. & International Marketing Strategy Concept & 156 & 13 & 0.927 \\
\hline 2. & Brand Orientation Concept & 156 & 6 & 0.806 \\
\hline 3. & Financial Performance Concept & 156 & 9 & 0.609 \\
\hline 4. & Brand Performance Concept & 156 & 5 & 0.604 \\
\hline 5. & International Commitment Concept & 156 & 5 & 0.818 \\
\hline 6. & Brand Repositioning Concept & 156 & 6 & 0.980 \\
\hline 7. & Congruence of Marketing Environment Concept & 156 & 11 & 0.897 \\
\hline 8. & Control of International Branding Activities Concept & 156 & 3 & 0.825 \\
\hline
\end{tabular}

Table 3. Multi-collinearity of demographics as a regressor

\begin{tabular}{llllll}
\hline & & $\mathbf{1}$ & $\mathbf{2}$ & $\mathbf{3}$ & $\mathbf{4}$ \\
\hline $\mathbf{1 .}$ & BUS & $\ldots$. & & & \\
2. & OWN & .240 & $\ldots$. & & \\
3. & EXP & .365 & .256 & $\ldots \ldots$ & \\
4. & SIZE & .325 & .060 & .023 & $\ldots .$. \\
\hline
\end{tabular}

Note. Matrix's cells $=\mathrm{n}(\mathrm{n}-1) / 2,\{4(4-1) / 2=\mathbf{6}\}$ cells.

Table 4. Multi-collinearityof control of branding activities as a regressor

\begin{tabular}{llll}
\hline & $\mathbf{1}$ & $\mathbf{2}$ & $\mathbf{3}$ \\
\hline CIBA1 & $\ldots$. & & \\
CIBA2 & .751 & $\ldots$. & $\ldots$. \\
CIBA3 & 0.430 & .751 & $\ldots$. \\
\hline
\end{tabular}

Note. Matrix's cells $=3(3-1) / 2,\{3(3-1) / 2=\mathbf{3}\}$ cells. 
Table 5. Multi-collinearity of international financial performance (FP) as a regressor

\begin{tabular}{|c|c|c|c|c|c|c|c|c|c|}
\hline & 1 & 2 & 3 & 4 & 5 & 6 & 7 & 8 & 9 \\
\hline FP1 & $\ldots$ & & & & & & & & \\
\hline FP2 & .164 & $\ldots$ & & & & & & & \\
\hline FP3 & .017 & .375 & $\ldots$ & & & & & & \\
\hline FP4 & .053 & .300 & .223 & $\ldots$ & & & & & \\
\hline FP5 & .041 & .041 & .405 & .073 & $\ldots$ & & & & \\
\hline FP6 & .052 & .209 & .054 & .259 & .356 & $\ldots$ & & & \\
\hline FP7 & .177 & .064 & .161 & .017 & .318 & .183 & $\ldots$ & & \\
\hline FP8 & .079 & .004 & .048 & .357 & .128 & .422 & .020 & $\ldots$ & \\
\hline FP9 & .001 & .170 & .253 & .301 & .113 & .478 & .126 & .635 & .... \\
\hline
\end{tabular}

Table 6. Multi-collinearity of brand performance (BP) as a regressor

\begin{tabular}{llllll}
\hline & $\mathbf{1}$ & $\mathbf{2}$ & $\mathbf{3}$ & $\mathbf{4}$ & $\mathbf{5}$ \\
\hline BP1 & $\ldots$ & & & & \\
BP2 & .054 & $\ldots$. & & & \\
BP3 & .166 & .048 & $\ldots$. & & \\
BP4 & .092 & .720 & .376 & $\ldots$. & \\
BP5 & .160 & .199 & .596 & .134 & $\ldots$. \\
\hline
\end{tabular}

Note. Matrix's cells $=5(5-1) / 2,\{5(5-1) / 2=\mathbf{1 0}\}$ cells.

Table 7. Multi-collinearity of international commitment (ICOM) as a regressor

\begin{tabular}{llllll}
\hline & $\mathbf{1}$ & $\mathbf{2}$ & $\mathbf{3}$ & $\mathbf{4}$ & $\mathbf{5}$ \\
\hline ICOM1 & $\ldots .$. & & & & \\
ICOM2 & .374 & $\ldots$. & & & \\
ICOM3 & .813 & .513 & $\ldots$. & & \\
ICOM4 & .485 & .888 & .422 & $\ldots$. & \\
ICOM5 & .089 & .547 & .232 & .448 & $\ldots .$. \\
\hline
\end{tabular}

Note. Matrix's cells $=5(5-1) / 2,\{5(5-1) / 2=\mathbf{1 0}\}$ cells.

Table 8. Multi-collinearity of brand repositioning (BR) regressors

\begin{tabular}{lllllll}
\hline & $\mathbf{1}$ & $\mathbf{2}$ & $\mathbf{3}$ & $\mathbf{4}$ & $\mathbf{5}$ & $\mathbf{6}$ \\
\hline BR1 & $\ldots$. & & & & & \\
BR2 & .234 & $\ldots$. & & & & \\
BR3 & .800 & .200 & $\ldots$. & & & \\
BR4 & .300 & .534 & .456 & $\ldots$. & & \\
BR5 & .400 & .234 & .564 & .432 & $\ldots$. & \\
BR6 & .500 & .456 & .765 & .346 & .456 & $\ldots .$. \\
\hline
\end{tabular}

Note. Matrix's cells $=6(6-1) / 2,\{6(6-1) / 2=15\}$ cells.

For instrument's validity, grouped discussions with colleagues and fellow academics suggested some minor paraphrasing and typo amendments to align the questionnaire with GCC's culture. Statistically, scale's validity is the degree to which a test measures the concept(s) that it claims measuring (e.g. Lotayif, (2014; and Nunnally, 1978). There is no common test for scale's Validity (Kline, 1997). Stodnicket al., (2008); Saravanan et al., (2007); Lotayif, (2004); ; Keil et al., (2000); have discussed the validity concept. These types are face, contents, predictive (criterion-related validity), construct, concurrent, convergent, divergent, and discriminant validities. 
Table 9. Multi-collinearity of congruence of marketing environment (CUE) as a regressor

\begin{tabular}{|c|c|c|c|c|c|c|c|c|c|c|c|}
\hline & 1 & 2 & 3 & 4 & 5 & 6 & 7 & 8 & 9 & 10 & 11 \\
\hline CUE1 & $\ldots$ & & & & & & & & & & \\
\hline CUE2 & .059 & $\ldots$ & & & & & & & & & \\
\hline CUE3 & .439 & .532 & $\ldots$ & & & & & & & & \\
\hline CUE4 & .196 & .782 & .680 & $\ldots$ & & & & & & & \\
\hline CUE5 & .439 & .532 & .234 & .680 & $\ldots$ & & & & & & \\
\hline CUE6 & .196 & .782 & .680 & .456 & .680 & $\ldots$ & & & & & \\
\hline CUE7 & .196 & .286 & .680 & .418 & .680 & .418 & $\ldots$ & & & & \\
\hline CUE8 & .059 & .577 & .532 & .782 & .532 & .782 & .782 & $\ldots$ & & & \\
\hline CUE9 & .059 & .154 & .532 & .286 & .532 & .286 & .782 & .577 & $\ldots$ & & \\
\hline CUE10 & .045 & .443 & .439 & .646 & .439 & .646 & .646 & .826 & .826 & $\ldots$ & \\
\hline CUE11 & .059 & .154 & .532 & .286 & .532 & .286 & .286 & .154 & .577 & .443 & $\ldots$ \\
\hline
\end{tabular}

Note. Matrix's cells $=11(11-1) / 2,\{11(11-1) / 2=\mathbf{5 5}\}$ cells.

Firstly, face validity describe the appropriateness level of questionnaire to the mission. Consequently, it describes everything related to collecting the needed data for the targeted aim. More specifically, from questions design and order, to number of questions to be included, to number of concepts, to editing typo and grammatical mistakes etc. Having said that, the appropriate way to measure that type of validity is field experts' opinions. Therefore, it is judgmental in nature and might differ from study to study. (Lotayif, 2015a; 2004). Secondly, content validity describes the appropriate coverage of the topics being studied (Rust and Golomok, 1999). To ensure face and content validities, the study's survey was edited by fellow academics for consultation and industry experts for better alignment between study survey and GCC culture. Then the study's survey was amended accordingly. As the current study is using a ready-made survey, some minor amendments have been taken for alignment with GCC's culture. Thirdly, construct validity describes the level of construct(s) appropriateness for usage (Bryman and Cramer, 1999). As the instrument is made of eight main and well know constructs (e.g. Wong, and Merrilees, 2007), construct validity and all other types of validities are supported.

\subsection{Testing Study Hypotheses}

As shown in Table (10), there are significant causality relationships between designing the international marketing strategy (IMS) and study's demographics, brand orientation, financial performance, brand performance, international commitment, brand repositioning, congruence of marketing environment, and control of international branding activities as $p \leq 0$. 05. Therefore, hypotheses from $H_{1}$ to $H_{8}$ are supported. In this perspective, the most remarkable things here are:

- Data entry order process did not affect on its analysis, as Durbin-Watson test reported values $>1.4$ for all dependent variables, as shown in Table (10).

- Statistically, "R square" and "adjusted R square" represent the model explanation' powers in the analyzed sample and in population (sometimes called model's generalizeability) respectively.

- The explanation powers of these eight positive models represented by "R square" and "adjusted $\mathrm{R}$ square" are medium and low, as they reported values like 34.2, 34, 37.8, 46.7, 32.6, 53.3, 63.3 and 30.1 percent and 23.4, 23.3, 22.1, 36.3, 20.6, 42.1, 51.2 and 21.1 percent for "R square" and "adjusted R square" respectively.

- Statistically, the existence of causality relationship does not guarantee the existence of significant relationships between all IVs components in the equation and the dependent variable but it does guarantee only the existence of at least one significant relationship (Lotayif, 2004, p. 261). Therefore, checking coefficient values help explain the real significant relationships between any set of variables as IVs and any DV.

Congruence of marketing environment represents the highest explanation power as "adjusted R square" is 51.2 percent. Implicitly, the behavior of international marketing strategy as a DV is affected by the components of marketing environment as IVs. That means the senior executives who are designing the marketing strategy are fully aware of and considering foreign markets features in their decisions. Explicitly and using variables coefficient values (i.e. $B$ value and $P$-value) that reported values less than 0.05 , these environmental features are the instability of foreign markets (CUE1, $B$ value $=0.319$ and $P$-value $=0.001$ ), customers are behaving differently in foreign markets (CUE2, $B$ value $=0.277$ and $P$-value $=0.021$ ), disposable incomes in foreign markets are relatively low $(\mathrm{CUE} 3, B$ value $=0.519$ and $P$-value $=0.040$ ), the motivations of customers in the foreign markets are harder to understand (CUE5, $B$ value $=0.674$ and $P$-value $=0.000$ ), people 
in foreign markets tend to value individual time more (CUE6, $B$ value $=0.564$ and $P$-value $=0.031$ ), interpersonal relationships in foreign markets are more important (CUE7, $B$ value $=0.619$ and $P$-value $=0.031$ ), visual aspects such as packaging and colours are more important in foreign markets (CUE9, $B$ value $=0.434$ and $P$-value $=0.000)$. Also, the distribution systems in foreign markets are more complex (CUE10, $B$ value $=0.674$ and $P$-value $=0.001$ ), and in relation to the domestic market, the cultures in foreign market are totally different (CUE11, $B$ value $=0.387$ and $P$-value $=0.041)$. However, two of the eleven marketing environment's components $\{$ i.e. customers in foreign markets are wealthier (CUE4, $B$ value $=0.024$ and $P$-value $=0.453$ ), and the technological knowledge of customers in foreign markets is more sophisticated (CUE8, $B$ value $=0.045$ and $P$-value $=0.564)\}$ reported no relationships as coefficient values are more than 0.05 .Threfore, the ramifications for decisions makers are crucial as these variables should be considered whenever thinking in designing the appropriate international strategy.

Table 10. Multiple regressions between international marketing strategy designing (as DV) and demographics, brand orientation, financial performance, brand performance,international commitment brand repositioning, congruence of marketing environment, and control of international branding activities (as, IVS)

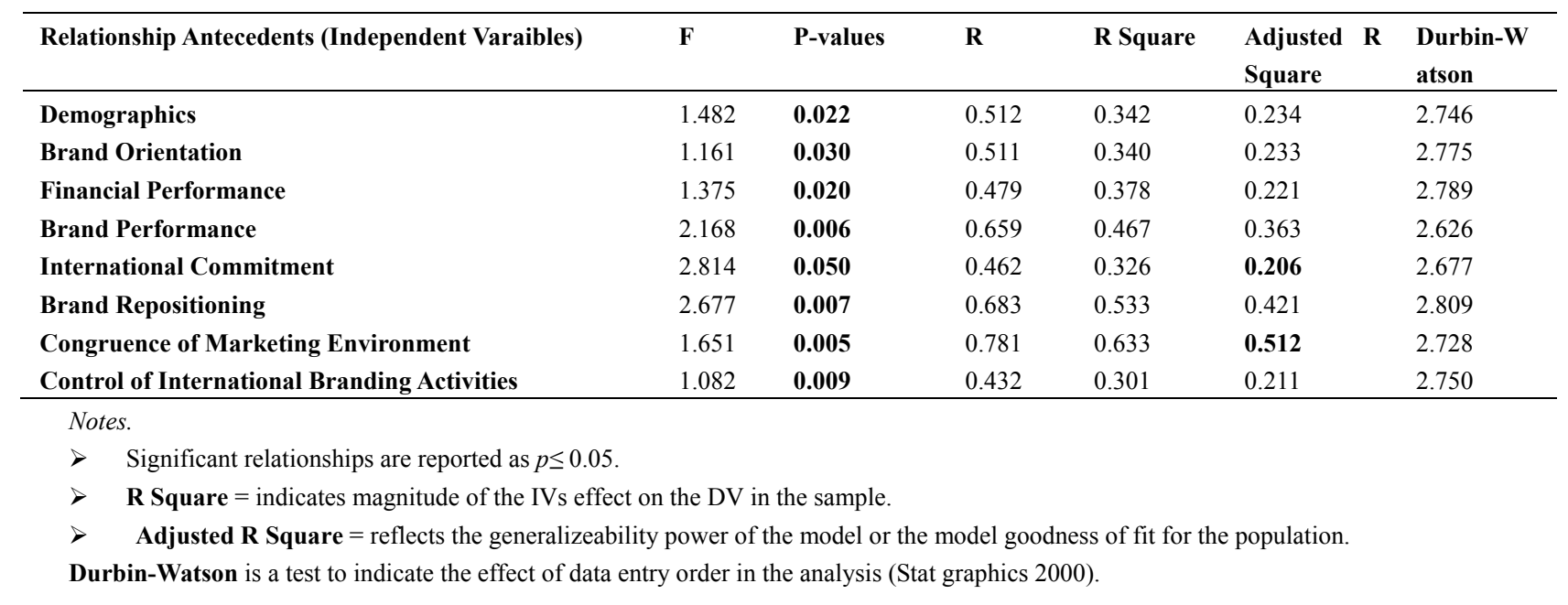

- On the other hand, international commitment reported the lowest explanation power as "adjusted $\mathrm{R}$ square" is 20.6 percent. The five commitment's variables are promising of pledging resources to international ventures (ICOM1, $B$ value $=0.325$ and $P$-value $=0.035)$, the extent of management commitment to the international marketing venture is substantial (ICOM2, $B$ value $=0.211$ and $P$-value $=0.030$ ), setting aside adequate funds to develop overseas markets (ICOM3, $B$ value $=0.210$ and $P$-value $=0.000$ ), and executives travel frequently to foreign markets (ICOM4, $B$ value $=0.431$ and $P$-value $=0.000$ ). However, insignificant relationship is existed between IMS and the management perception of international business as a high priority (ICOM5, $B$ value $=0.032$ and $P$-value $=0.742$ ) which reflects limited level of commitment of GCC companies for foreign markets.

- $\quad$ Annex, brand repositioning affects the behavior of international marketing strategy by 42.1 percent. The detailed weights as indicated by coefficient's values are as follows; compared to the domestic market, the quality of the products in the foreign markets was increased (BR1 $B$ value $=0.230$ and $P$-value $=0.030$ ); the approaches of promotion/advertising in the foreign markets were different (BR3, $B$ value $=0.110$ and $P$-value $=0.001$ ); the product features in the foreign markets were different (BR4, $B$ value $=0.320$ and $P$-value $=0.041$ ); the distinctive identity of the brand in the foreign markets was different (BR5, value $=0.131$ and $P$-value $=0.021$ ); and the distribution of the brand in foreign markets require different methods of distribution/outlet (BR6, $B$ value $=0.131$ and $P$-value $=0.021)$. However, compared to the domestic market, the target market of the brand in the foreign markets was moved upmarket (BR2) is not correlated with international marketing strategy as $B$ value $=$ 0.012 and $P$-value $=0.542$. Therefore, decision makers ought to consider these variables of brand repositioning whenever design or redesign the international marketing strategy.

- Alsobrand performance affects the behavior of international marketing strategy by 36.3 percent. The detailed weights as indicated by coefficient's values are as follows; marketing strategy is working well (BP1, $B$ value $=0.130$ and $P$-value $=0.030)$; building a strong brand awareness in the target $\operatorname{market}(\mathrm{s})(\mathrm{BP} 2, B$ value $=$ 
0.210 and $P$-value $=0.001) ; \quad$ building a solid brand reputation $(\mathrm{BP} 3, B$ value $=0.121$ and $P$-value $=0.011$ ); ensuring satisfaction with current brand marketing $(\mathrm{BP} 4, B$ value $=0.231$ and $P$-value $=0.031)$; and building strong customer brand loyalty $(\mathrm{BP} 5, B$ value $=0.111$ and $P$-value $=0.010)$. Therefore, decision makers ought to consider these variables of brand performance whenever design or redesign the international marketing strategy.

- At the same time, the analysis revealed that demographical factors affect the behavior of international marketing strategy by 23.4 percent, as shown in Table (10). The detailed weights as indicated by coefficient's values are as follows; types of business (BUS, $B$ value $=0.230$ and $P$-value $=0.010)$, types of ownership (OWN, $B$ value $=0.112$ and $P$-value $=0.000)$, business experience $($ EXP, $B$ value $=0.330$ and $P$-value $=0.000)$, and business sizes (SIZE, $B$ value $=0.351$ and $P$-value $=0.020$ ). Consequently, decision makers ought to consider these demographic variables whenever design or redesign the international marketing strategy.

- Also, brand orientation affects the behavior of international marketing strategy by 23.3 percent, as shown in Table (10). The detailed weights as indicated by coefficient's values are as follows: the stress on branding across all marketing activities (BO1, $B$ value $=0.210$ and $P$-value $=0.011$ ); the vital role the brand has in building the comprehensive strategy $(\mathrm{BO} 2, B$ value $=0.112$ and $P$-value $=0.000$ ); branding is crucial in running the company $(\mathrm{BO}, B$ value $=0.301$ and $P$-value $=0.000)$; long term brand planning is essential to future success $(\mathrm{BO} 4, B$ value $=0.151$ and $P$-value $=0.041)$; brand is recognized as a vital intangible asset $(\mathrm{BO}$, $B$ value $=0.151$ and $P$-value $=0.001)$; and branding is perceived as everybody top priority $(\mathrm{BO}, B$ value $=$ 0.311 and $P$-value $=0.022$ ). Therefore, decision makers ought to consider these variables of brand orientation whenever design or redesign the international marketing strategy.

- Moreover, only four variables out of the nine financial performance's variables affect, significantly, the behavior of international marketing performance by 22.1 percent, as shown in Table (10). These variables are as follows: foreign markets sales' performances are satisfactory (FP5, $B$ value $=0.411$ and $P$-value $=0.012$ ); the trust of the potentiality of foreign markets (FP7, $B$ value $=0.300$ and $P$-value $=0.021$ ), the sales' ratio from foreign markets (compared to domestic markets) met the expectations (FP8, $B$ value $=0.301$ and $P$-value $=$ 0.002 ), and the profit's ratio from foreign markets met the expectations (FP9, $B$ value $=0.370$ and $P$-value $=$ 0.023). The other five variables reported insignificant relationships with IMS, as the regression equation guarantee the existence of at least one significant relationship. Therefore, decision makers ought to consider these variables of financial performance whenever design or redesign the international marketing strategy.

- Finally, control of international branding activities affect, significantly, the behavior of international marketing performance by 21.1 percent, as shown in Table (10). These detailed variables are as follows: having sufficient influences over the marketing process (CIBA1, $B$ value $=0.360$ and $P$-value $=0.033$ ), controlling the decision-making process of foreign operations (CIBA2, $B$ value $=0.311$ and $P$-value $=0.012$ ), and making all taken decisions related to the integrity of the brand $(\mathrm{CIBA} 3, B$ value $=0.310$ and $P$-value $=0.022)$. Therefore, decision makers ought to consider these variables of controlling international branding activities whenever design or redesign the international marketing strategy.

\section{Discussions}

The current research might be seen as a pioneer endeavor in testing IMS components in this area of the world i.e. GCC district. The eight branding variable that have been tested in this study reported positive causality relationships with international marketing strategy. Apart from congruence of marketing environment that reported a medium influence, the rest of variables reported weak significant relationships as indicated by adjusted R square values. Therefore, other variables could be included in future researches. In this perspective, other scholars are invited to explore other variables rather than these have been tested in the current research.

Despite the economic booming that have been achieved in GCC economies, the main giant gulf companies still not giving enough priority to foreign markets. Therefore, decision makers in these companies are invited for devoting more efforts for these foreign markets. In this perspective, only 20 percent of the senior executives agreed when asked about putting international business in a high priority in their companies. But the good thing here is almost two-third of the responded executives are perceiving the importance of international commitments like resources commitment, and developing overseas markets, travelling from every now and then to these markets, as shown in Table (11).

Moreover, GCC giant companies are aware of the overseas marketing environment like the instability features of these markets, the differences in culture between demotic and foreign markets customers and the reflections on their preferences, the lower disposable income in these foreign markets and the reflections on pricing policies designed for these markets. Also, they are aware of the differences in customers' motivation and the reflections on the deployed motivational mix, the busy nature of overseas customers and reflections on the importance of 
customer's time. Not only that but also, they are aware of using the interpersonal approach in promotion and the reflection of the importance of personal selling in these markets, the importance of packaging and the reflections on visual design of the promotional mix, the complexity nature of the distribution networks and the reflections on selecting the appropriate distribution channels that fit every market. However, these giant GCC companies ought to focus on the importance of technology in these overseas markets, as 85.9 percent denying that claim, as explained in Table (11).

Annex, for designing the international marketing strategy (IMS), firms working in the GCC region are modifying, to great extent, their products (IMS1 by 83.3 percent), emphasizing product quality and warranties (IMS2 by 54 percent), eliminating products that does not meet customer's expectations (IMS4 by 56.4 percent), effectively engaging in prices' analysis of the current rivals (IMS5 by 67.3percent), setting strategic promotional objectives (IMS7 by 58.3 percent), carefully developing advertising and promotion messages (IMS8 by 59 percent), providing after sales services (IMS9 by 73.7 percent), building strong relationship with distributors (IMS10 by 61.5 percent), providing lots of channel support (IMS11 by 73.7 percent), carefully evaluating alternative channels of distribution (IMS12 by 67.9 percent), and engaging in effective programs for dealer relations. (IMS13 by 62.2 percent). Therefore, they are conducting most of the international marketing strategy components (i.e. 11 out of 13 items) by a satisfactory way. However, they are not engaging in the process of lunching new product/service (IMS3 by 26.3 percent only), and they are not offering discounts regularly (IMS6 by 42.3 percent). Finally, the study results go hand in hand with the main stream line of literature in this regard. More specifically, it confirmed Wong, and Merrilees's study (2007) about the importance of branding activities on designing the marketing strategy.

Table 11. Frequency of study's variables

\begin{tabular}{|c|c|c|c|c|c|c|c|c|c|c|c|}
\hline Variables & $\begin{array}{c}\text { Agree } \\
\%\end{array}$ & $\begin{array}{c}\text { Disagree } \\
\%\end{array}$ & Variables & $\begin{array}{c}\text { Agree } \\
\%\end{array}$ & $\begin{array}{c}\text { Disagree } \\
\%\end{array}$ & Variables & $\begin{array}{c}\text { Agree } \\
\%\end{array}$ & $\begin{array}{c}\text { Disagree } \\
\%\end{array}$ & Variables & $\begin{array}{c}\text { Agree } \\
\%\end{array}$ & $\begin{array}{c}\text { Disagree } \\
\%\end{array}$ \\
\hline IMS1 & 83.3 & 13.7 & BR1 & 73.1 & 26.9 & BP1 & 61.0 & 39.0 & BO1 & 23.7 & 76.3 \\
\hline IMS2 & 54.0 & 46,0 & BR2 & 73.1 & 26.9 & BP2 & 68.8 & 31.4 & BO2 & 63.5 & 36.5 \\
\hline IMS3 & 26.3 & 73.7 & BR3 & 63.5 & 36.5 & BP3 & 68.8 & 31.4 & BO3 & 36.5 & 63.5 \\
\hline IMS4 & 56.4 & 43.6 & BR4 & 63.5 & 36.5 & BP4 & 63.5 & 36.5 & BO4 & 73.7 & 26.3 \\
\hline IMS5 & 67.3 & 32.7 & BR5 & 63.5 & 36.5 & BP5 & 77.6 & 22.4 & BO5 & 51.9 & 48.1 \\
\hline IMS6 & 42.3 & 57.7 & BR6 & 63.5 & 36.5 & ICOM1 & 63.3 & 36.5 & BO6 & 52.6 & 47.4 \\
\hline IMS7 & 58.3 & 41.7 & CUE1 & 71.8 & 28.2 & ICOM2 & 76.9 & 23.2 & CUE8 & 21.2 & 78.8 \\
\hline IMS8 & 59.0 & 41.0 & CUE2 & 78.8 & 21.2 & ICOM3 & 72.4 & 27.6 & CUE9 & 78.8 & 21.2 \\
\hline IMS9 & 73.7 & 26.3 & CUE3 & 92.9 & 7.1 & ICOM4 & 72.4 & 27.6 & CUE10 & 71.8 & 28.2 \\
\hline IMS10 & 61.5 & 38.5 & CUE4 & 14.1 & 85.9 & ICOM5 & 20.0 & 80.0 & CUE11 & 78.8 & 21.2 \\
\hline IMS11 & 73.7 & 26.3 & CUE5 & 92.9 & 7.1 & CIBA1 & 84.4 & 15.4 & \multirow[t]{3}{*}{ FP4 } & $\leq 50$ & 40 \\
\hline IMS12 & 67.9 & 32.1 & CUE6 & 85.9 & 14.1 & CIBA2 & 75.6 & 21.4 & & $\leq 25$ & 30 \\
\hline IMS13 & 62.2 & 37.8 & CUE7 & 85.9 & 14.1 & CIBA3 & 84.6 & 15.4 & & $\geq 25$ & 30 \\
\hline FP1 & $\leq 50$ & $50 \%$ & FP2 & $\leq 50$ & 55 & \multirow[t]{3}{*}{ FP3 } & $\leq 50$ & 20 & \multicolumn{3}{|l|}{ Note: } \\
\hline \multirow{5}{*}{ FP5 } & $\leq 25$ & $30 \%$ & \multirow{5}{*}{ FP6 } & $\leq 25$ & 24 & & $\leq 25$ & 30 & \multirow{5}{*}{\multicolumn{3}{|c|}{$\begin{array}{l}\text { The full names of each and } \\
\text { every variables is fully } \\
\text { mentioned and explained in } \\
\text { study questionnaire in Appendix } \\
\text { (A) }\end{array}$}} \\
\hline & $\geq 25$ & $20 \%$ & & $\geq 25$ & 21 & & $\geq 25$ & 50 & & & \\
\hline & $\leq 50$ & 54 & & $\leq 50$ & 60 & FP7 & 41.6 & 58.4 & & & \\
\hline & $\leq 25$ & 46 & & $\leq 25$ & 20 & FP8 & 48.7 & 51.3 & & & \\
\hline & $\geq 25$ & 0 & & $\geq 25$ & 20 & FP9 & 59.6 & 40.4 & & & \\
\hline
\end{tabular}

\subsection{Conclusion and Recommendations}

The current research could be considered a pioneer endeavor to determine the branding variables affecting the designing of international marketing strategy (IMS) in GCC context. The study revealed that there are significant causality relationships between designing the international marketing strategy (IMS) and study's demographics, brand orientation, financial performance, brand performance, international commitment, brand repositioning, congruence of marketing environment, and control of international branding activities.

Also, the research revealed that, whenever designing the marketing strategy, GCC senior executives are fully aware of and considering foreign markets features in their taken decisions. These are: instability of foreign markets; customers are behaving differently in foreign markets; disposable incomes in foreign markets are relatively low; the motivations of customers in the foreign markets are harder to understand; people in foreign 
markets tend to value individual time more; interpersonal relationships in foreign markets are more important; visual aspects such as packaging and colours are more important in foreign markets; the distribution systems in foreign markets are more complex; and in relation to the domestic market, the cultures in foreign market are totally different. However, the research revealed limited level of commitment of GCC companies for foreign markets. Also, whenever designing the marketing strategy, GCC senior executives are fully aware of brand repositioning components that fit foreign markets. These are: enhancing the quality for foreign markets; using different approaches of promotion/advertising designed specifically for foreign markets; different product features for foreign markets; different distinctive identity of the brand is stressed for foreign markets; and different distribution channels are designed for different foreign markets.

Moreover, brand performance variables that ought to be considered whenever designing IMS are ensuring that marketing strategy is working well, building a strong brand awareness in the target markets, building a solid brand reputation, ensuring satisfaction with current brand marketing, and building strong customer brand loyalty. Also, businesses demographics (e.g. types of activity, ownerships, experience, and sizes) ought to be considered whenever designing IMS. Also, the current research revealed the financial performance's variables that ought to be considered whenever designing the IMS. These are: sales from current and potential foreign markets; and rations of foreign-domestic sales and profit.

However, the limited magnitude of causality relationships, as indicated by adjusted R square could be enhanced by revisiting the concept's components in the tested questionnaire. More specifically, adding more variables to controlling variables, and using secondary quantitative data for measuring the brand performance might help enhance the relationships' magnitudes in this perspective. Therefore, other scholars are invited for that research mission with evidences from other regions.

Finally, the current findings help in designing and redesigning an effective strategy dealing with international marketing marketplaces. Also, it filled part of the literature gap in branding effects outside USA market and international marketing strategy as recommended by many \{e.g. Leonidas et al., (2010); Wong and Merrilees (2007); Varadarajan and Jayachandran (1999); Malhotra et al., (1999); Douglas and Craig (1992) and Albaum and Peterson (1984)\}.

\section{References}

Agrawal, M. (1995). Review of a 40-Year Debate in International Marketing.International Marketing Review, 12(1), 26-48. http://dx.doi.org/10.1108/02651339510080089.

Alashban, A. A., Hayes, L. A., Zinkhan, G. M., \& Balazs, A. L. (2002). International Brand-Name Standardization/adaptation: Antecedents and Consequences. Journal of International Marketing, 10(3), 22-48. http://dx.doi.org/10.1509/jimk.10.3.22.19544.

Albaum, G., \& Peterson, R. A. (1984). Empirical Research in International Marketing: 1976-1982. Journal of International Business Studies, (Spring/Summer), 161-173. http://dx.doi.org/10.1057/palgrave.jibs.8490479.

Appiah-Adu, K. (1997). Marketing in Emerging Countries: Evidence from a Liberalized Economy.Marketing Intelligence and Planning, 15(6), 291-298. http://dx.doi.org/10.1108/02634509710184893.

Biel, A. L. (1992). How Brand Image Drives Brand Equity. Journal of Advertising Research, 32(6), 6-12.

Black, J. A., \& Boal, K. B. (1994). Strategic Resources: Traits, Configurations and Paths to Sustainable Competitive Advantage.Strategic Management Journal, 15, 131-148. http://dx.doi.org/10.1002/smj.4250151009.

Bond, M. H. et al. (2004). Culture-level Dimensions of Social Axioms and their Correlates Across 41 Cultures. Journal of Cross-cultural Psychology, 35(5), 548-570. https://doi.org/10.1177/0022022104268388.

Bryman, A., \& Cramer, D. (1999). Quantitative Data analysis with SPSS Release 8 for Windows: A Guide for Social Scientists. London: Routledge. http://dx.doi.org/10.4324/9780203459621

Calderon, H., Cervera, A., \& Molla, A. (1997). Brand Assessment: a Key Element of Marketing Strategy. Journal of Product and Brand Management, 6(5), 293-304. http://dx.doi.org/10.1108/10610429710179462.

Cavusgil, S. T., \& Zou, S. (1994). Marketing Strategy-Performance Relationship: An Investigation of the Empirical Link in Export Market Ventures. Journal of Marketing, 58(1), 1-21. http://dx.doi.org/10.2307/1252247.

Chan, Y., Huff, S., \& Copeland, D. G. (1998). Assessing Realized Information Systems Strategy. Journal of Strategic Information Systems, 6, 273-298. http://dx.doi.org/10.1016/S0963-8687(97)00005-X 
Chapman, M. (1997). Social Anthropology, Business Studies, and Cultural Issues. International Studies of Management \& Organization, 26(4), 3-29. https://doi.org/10.1080/00208825.1996.11656692

Chaudhuri, A., \& Holbrook, M. B. (2001). The Chain of Effects from Brand Trust and Brand Affect to Brand Performance: The Role of Brand loyalty.Journal of Marketing, 65(2), 81-93. http://dx.doi.org/10.1509/jmkg.65.2.81.18255.

Cheng, J. M. S., Blankson, C., Wu, P. C. S., \& Chen, S. S. M. (2005). A Stage Model of International Brand Development: The Perspectives of Manufacturers from Two Newly Industrialized Economies -South Korea and Taiwan. Industrial Marketing Management, 34, 504-514. http://dx.doi.org/10.1016/j.indmarman.2004.09.009.

Czinkota, M. R., \& Ronkainen, I. A. (2007). International Marketing. Thomson Mason, OH, USA.

Czinkota, M. R., Ronkainen, I. A., Moffett, M. H., \& Moynihan, E. O. (2001). Global Business. Harcourt, Inc., Orlando, FL.

De Chernatony, L. (2001). From Brand Vision to Brand Evaluation: Strategically Building and Sustaining Brands. Butterworth-Heinemann, Oxford.

Deli, Y., Mahmut (Maho), S., Qinghai, L., \& Yibing, D. (2015). The Power of Triple Contexts on Customer-based Brand Performance-A Comparative Study of Baidu and Google from Chinese Netizens' Perspective. International Business Review, 24, 11-22. https://doi.org/10.1016/j.ibusrev.2014.05.004

D'Iribarne, P. (1997). The Usefulness of an Ethnographic Approach to the International Comparison of Organizations.International Studies of Management \& Organization, 26(4), 30-47. https://doi.org/10.1080/00208825.1996.11656693

Dong, L.C., \& Marilyn, M. H. (2001). Brand Name Translation Model: a Case Analysis of US Brands in China. Journal of Brand Management, 9(2), 99-115. http://dx.doi.org/10.1057/palgrave.bm.2540058

Douglas, S.P., \& Craig, C.S. (1992). Advances in International Marketing. International Journal of Research in Marketing, 9(4), 291-318. http://dx.doi.org/10.1016/0167-8116(92)90002-3

Driscoll, A.M., \& Paliwoda, S.J. (1997). Dimensionalizing International Market Entry Mode Choice. Journal of Marketing Management, 13(1-3), 57-87. http://dx.doi.org/10.1080/0267257x.1997.9964459.

Evangelista, F. U. (1994). Export Performance and its Determinants: Some Empirical Evidence from Australian Manufacturing Firms.Advances in International Marketing, 6, 207-29.

Francis, G. (2001). Introduction to SPSS for Windows (3rd ed.). Australia: Pearson Education.

Francis, J. N. P., Lam, J. P. Y., \& Walls, J. (2002). Executive insights: the Impact of Linguistic Differences on International Brand Name Standardization: A Comparison of English and Chinese Brand Name of Fortune-500 Companies. Journal of International Marketing, 10(1), 98-116. http://dx.doi.org/10.1509/jimk.10.1.98.19528

Ganesh, J., \& Oakenfull, G. (1999). International Product Positioning: an Illustration Using Perceptual Mapping Techniques.Journal of Global Marketing, 13(2), 85-111. http://dx.doi.org/10.1300/J042v13n02_06

Ghiselli, E., Campbell, J., \& Zedeck, S. (1981). Measurement Theory for the Behavioral Sciences. San Francisco, USA.

Grant, R.M. (1991). The Resource-based Theory of Competitive Advantage: Implications for Strategy Formulation. California Management Review, 33(3), 114-135. http://dx.doi.org/10.2307/41166664

Hall, E. T. (1960). The Silent Language in Overseas Business.Harvard Business Review, 38(3), 87-96.

Hall, E. T. (1970). Beyond Culture. Anchor Press/Doubleday, Garden City, NY.

Hart, S. (1987). The Use of the Survey in Industrial Market Research. Journal of Marketing Management, 3(1), 25-38. http://dx.doi.org/10.1080/0267257X.1987.9964025.

Ho, Y. W., \& Bill, M. (2015). An Empirical Study of the Antecedents and Consequences of Brand Engagement. Marketing Intelligence \& Planning, 33(4), 575-591. https://doi.org/10.1108/MIP-08-2014-0145

Hofstede, G. (1980). Culture's Consequences: International Differences in Work-related Values. Sage, Beverly Hills, CA.

Hofstede, G. (1983). The Cultural Relativity of Organizational Practices and Theories. Journal ofInternational Business Studies, 14, 75-89. https://doi.org/10.1057/palgrave.jibs.8490867 
Hofstede, G. (2001). Culture's Consequences: Comparing Values (2nd ed.). Behaviors, Institutions, and Organizations Across Nations., Sage, Thousand Oaks, CA.

House, R. J., Hanges, P. J., Javidan, M., Dorfman, P., \& Gupta, V. (2004). GLOBE Cultures, Leadership, and Organizations: GLOBE Study of 62 Societies. Sage, Newberry Park, CA.

Hsieh, M. H., \& Lindridge, A. (2005). Universal Appeals with Local Specifications.Journal of Product \& Brand Management, 14(1), 14-28. http://dx.doi.org/10.1108/10610420510583716

Keil, M., Mann, J., \& Rai, A. (2000). Why Software Projects Escalate: An Empirical Analysis and Test of Four Theoretical Models.MIS Quarterly, 24(4), 631-664.http://dx.doi.org/10.2307/3250950

Kline, P. (1997). An Easy Guide for Factor Analysis.Routledge, London.

Kotler, P. (1986). Global Standardization-courting Danger. The Journal of Consumer Marketing, 3(2), 13-15. http://dx.doi.org/10.1108/eb008158

Kotler, P., Fahey, L., \& Jatusriptak, S. (1985). The New Competition. Prentice-Hall, Englewood Cliffs, NJ.

Lazer, W., Murata, S., \& Kosaka, H. (1985). Japanese Marketing: Towards a Better Understanding.Journal of Marketing, 49, 68-81. https://doi.org/10.2307/1251566

Lee, J. E. (1966). Cultural Analysis in Overseas Operations.Harvard Business Review, 44(2), 106-114. https://doi.org/10.1002/tie.5060080303

Leonidas, C. L., Bradley, R. B., Stavroula, S., \& Constantine, S. K. (2010). Assessing the Contribution of Leading Mainstream Marketing, Journals to the International Marketing Discipline.International Marketing Review, 27(5), 491-518. http://dx.doi.org/10.1108/02651331011076563

Leung, K., Bhagat, R. S., Buchan, N. R., Erez, M., \& Gibson, C. B. (2005). Culture and International Business: Recent Advances and their Implications for Future Research. Journal of International Business Studies, 36(4), 357-378. https://doi.org/10.1057/palgrave.jibs. 8400150

Levine, R. A. (1984). Properties of Culture: An Ethnographic View. In Sheweder, R. A., \& Levine, R. A. (Eds.), Culture Theory: Essays on the Mind, Self, and Emotion. Cambridge University Press, Cambridge.

Levitt, T. (1983). The Globalization of Markets.Harvard Business Review, 61(3), 92-102.

Lotayif, M. (2005). Entry Modes and Different Marketing Strategies Models. In Kiefer Lee and Steve Carter (Eds.), Global Marketing Management (pp. 176-180). Oxford Press, United Kingdom.

Lotayif, M. (2014). Causality Relationship for Selection Variables of Brand Creation and Brand Acquisition as Expansion Strategies: Evidence from Egypt. The Journal of American Academy of Business, Cambridge (JAABC), 19(2), 287-285.

Lotayif, M. (2015a). University Industry (U-I) Relationship: Evidence from an Egyptian University. International Journal of Business and Management (IJBM), 10(4), 113-122. https://doi.org/10.5539/ijbm.v10n4p113

Lotayif, M. (2015b). The Components of Marketing Strategies Making (MSM) and the Relationships with Strategy Antecedents and Consequences: Evidences from Egypt.The Business Review, Cambridge (BRC), 2, $27-136$.

Lotayif, M. (2016). Selection Factors of Market Segments and Porter's Generic Marketing Strategies: Evidence from an Emerging GCC Market.International Journal of Business and Management (IJBM), 11(1), (January), 199-215. https://doi.org/10.5539/ijbm.v11n1p199

Lotayif, M., S. M. A. (2004). GATS Impacts on Entry Modes and Defensive Marketing Strategies in the Egyptian Banking Sector. Department of International Business, Plymouth Business School, University of Plymouth, UK.

Malhotra, N. K. (1993). Marketing Research an Applied Orientation. Prentice-Hall, Inc., New Jersey, USA.

Malhotra, N. K., Peterson, M., \& Kleiser, S.B. (1999). Market Research: a State-of-the-art Review and directions for the Twenty-first Century. Journal of the Academy of Marketing Science, 27(2), 160-183. http://dx.doi.org/10.1177/0092070399272004

Marc, F., Adamantios, D., Allan, C., \& Rachael, A. (2015). How are Brand Names of Chinese Companies Perceived by Americans? Journal of Product \& Brand Management, 24(2), 110-123. https://doi.org/10.1108/JPBM-02-2014-0501

Markus, H.R., \& Kitayama, S. (1991). Culture and the Self: Implications for Cognition, Emotion, and Motivation. 
Psychological Review, 98(2), 224-253.

Mavondo, F. T., \& Rodrigo, E. M. (2001). The Effect of Relationship Dimensions on Interpersonal and Interorganizational Commitment in Organizations Conducting Business between Australia and China. Journal of Business Research, 52(2), 111-121. http://dx.doi.org/10.1016/s0148-2963(99)00064-8

Moore, C. M., Fernie, J., \& Burt, S. (2000). Brands Without Boundaries: The Internationalisation of the Designer Retailer's Brand. European Journal of Marketing, 34(8), 919-937. http://dx.doi.org/10.1108/03090560010331414

Mosmans, A. (1996). Brand Strategy: Creating Concepts that Drive the Business. The Journal of Brand Management, 3(3), 156-165. http://dx.doi.org/10.1057/bm.1995.42

Mosmans, A., \& Van Der Vorst, R. (1998). Brand Based Strategic Management. The Journal of Brand Management, 6(2), 99-110. http://dx.doi.org/10.1057/bm.1998.51

Nunnally, J. C. (1978). Psychometric Theory (2nd eds.). New York: McGraw-Hill.

O'Donnell, S., \& Jeong, I. (2000). Marketing Standardization within Global Industries: An Empirical Study of Performance Implications. International Business Review, 17(1), 19-33. http://dx.doi.org/10.1108/02651330010314696

Ortuzar, J. D., \& Willumsen, L. G. (1994). Modeling Transport. New York: John Wiley and Sons Ltd.

Paliwoda, S. J. (1999). International Marketing: An Assessment.International Marketing Review, 16(1), 8-17. http://dx.doi.org/10.1108/02651339910257601

Peteraf, M.A. (1993). The Cornerstones of Competitive Advantage: A Resource-based View.Strategic Management Journal, 14(3), 179-191.http://dx.doi.org/10.1002/smj.4250140303

Preble, J.F., Rau, P. A., \& Reichel, A. (1988). The Environmental Scanning Practices of US Multinationals in the Late 1980s. Management International Review, 28(4), 4-14.

Ravichandran, T., \& Rai, A. (2000). Quality Management in Systems Development: An Organizational System Perspective. MIS Quarterly, 24(3), 381-415.

Reid, M. (2002. Building Strong Brands through the Management of Integrated Marketing Communications. International Journal of Wine Marketing, 14(3), 37-52. http://dx.doi.org/10.1108/eb008745

Ricks, D.A. (1993). Blunders in International Business. Blackwell, Cambridge.

Robinson, J. P., Shaver, P. R., \& Wrightsman, L. S. (1991). Criteria for Scale Selection and Evaluation. http://dx.doi.org/10.1016/B978-0-12-590241-0.50005-8

Rokeach, M. (1973). Nature of Human Values. New York, NY: The Free Press.

Rosen, B. N., Boddewyn, J. J., \& Louis, E. A. (1989). US Brands Abroad: An Empirical Study of Global Branding. International Marketing Review, 6(1), 7-19.

Rubinstein, H. (1996). Brand First' Management. Journal of Marketing Management, 12(4), 269-280. http://dx.doi.org/10.1080/0267257X.1996.9964414

Rugman, A. (2001a). The Myth of Global Strategy. International Marketing Review, 18(6), 583-588. http://dx.doi.org/10.1108/EUM0000000006300

Rugman, A. (2001b). The Myths of Globalization. Ivey Business Journal, 66(1), 64-68.

Rust, J., \& Golombok, S. (1999). Modern Psychometrics (2nd ed.). Routledge, London.

Sandler, D. M., \& Shani, D. (1992). Brand Globally But Advertise Locally? An Empirical Investigation.International Marketing Review, 9(4), 18-31. http://dx.doi.org/10.1108/02651339210017091

Saravanan, R., \&Rao, K. S. P. (2007). Measurement of Service Quality from the Customer's Perspective-An Empirical Study. Total Quality Management, 18(4), 435-449. http://dx.doi.org/10.1080/14783360701231872

Schwartz, S. H., \& Bilsky, W. (1990). Toward a Theory of the Universal Content and Structure of Values: Extensions and Cross-cultural Replications. Journal of Personality and Social Psychology, 58, 878-91. https://doi.org/10.1037/0022-3514.58.5.878

Shoham, I. G. A. (2014). Uncovering the Influence of the International Marketing Function in International Firms. International Marketing Review, 31(1), 51-78. http://dx.doi.org/10.1108/IMR-12-2012-0204

Silcoff, S. (2000). Second Time Friendly: Seven Eaton's Stores in Choice Downtown Locations Across Canada are 
about to be Reborn as, Wait for it, a Retail Chain for Urban Hipsters. Canadian Business, 73(10), 34.

Still, R.R., \& Hill, J.S. (1984). Adapting Consumer Products to Lesser-Developed Markets. Journal of Business Research, 12(1), 51-61. http://dx.doi.org/10.1016/0148-2963(84)90037-7

Stodnick, M., \& Pamela, R. (2008). Using SERVQUAL to Measure the Quality of the Classroom Experience Decision Sciences. Journal of Innovative Education, 6(1), 115-134. http://dx.doi.org/10.1111/j.1540-4609.2007.00162.x

Subramanian, R., Fernandes, N., \& Harper, E. (1993). Environmental Scanning in US Companies: their Nature and their Relationship to Performance. Management International Review, 33, 271-286.

Teo, T., and King, W. (1996). Assessing The Impact of Integrating Business Planning and IS Planning.Information and Management, 30, 309-332. http://dx.doi.org/10.1016/S0378-7206(96)01076-2

Terpstra, V. (2000). The Millennium and International Marketing.International Marketing Review, 17(1), 15-18. http://dx.doi.org/10.1108/02651330010314687

Urde, M. (1994). Brand orientation-a Strategy for Survival.Journal of Consumer Marketing, 11(3), 18-32. http://dx.doi.org/10.1108/07363769410065445

Urde, M. (1999). Brand Orientation: A Mindset for Building Brands into Strategic Resources.Journal of Marketing Management, 15(1-3), 117-133. http://dx.doi.org/10.1362/026725799784870504

Varadarajan, P. R.,\& Jayachandran, S. (1999). Marketing Strategy: An Assessment of the State of the Field and Outlook. Journal of the Academy of Marketing Science, 27(2), 120-143. http://dx.doi.org/10.1177/0092070399272002

Wernerfelt, B. (1984). A Resource-Based View of the Firm.Strategic Management Journal, 5(2), 171-180. http://dx.doi.org/10.1002/smj.4250050207

Will, J. S. C., \& Jacobs, L. (1991). Developing Global Products and Marketing Strategies: A Construct and a Research Agenda. Journal of the Academy of Marketing Science, 19(1), 1-10. http://dx.doi.org/10.1007/BF02723418

Wnnacott, T. H., \& Wonnacott, R. J. (1990). Introductory Statistics for Business and Economics. John Wiley and Sons Inc.

Wong, H. Y., \& Merrilees, B. (2006). Determinants of SME Brand Adaptation in Global Marketing. International Journal of Entrepreneurship and Small Business, 3(3-4), 477-497. http://dx.doi.org/10.1504/IJESB.2006.009288

Wong, H. Y., \& Merrilees, B. (2007). Multiple Roles for Branding in International Marketing. International Marketing Review, 24(4), 384-408. http://dx.doi.org/10.1108/02651330710760982

Yaprak, A. (2008). Culture Study in International Marketing: A Critical Review and Suggestions for Future Research.International Marketing Review, 25(2), 215-229. https://doi.org/10.1108/02651330810866290

Yovovich, B. G. (1988). What is a Brand Really Worth? Ad week's Marketing Week, 8, 18-20.

Zou, S., \& Cavusgil, S.T. (1996). Global strategy: A Review and an Integrated Conceptual Framework. European Journal of Marketing, 30(1), 52-69. http://dx.doi.org/10.1108/03090569610105799

Zou, S., David, M. A., \& Wayne, N. (1997). Standardization of International Marketing Strategy by Firms from a Developing Country.International Marketing Review, 14(2) 107-123. http://dx.doi.org/10.1108/02651339710170203

\section{Appendix (A)}

\section{Type of Business (BUS)}

a. Commercial ( )

b. Industrial ( )

c. Service ( )

d. Others ( )

2. Type of Ownership (OWN)

a. Private 
b. Public and Governmental ( )

\section{Business Experience (EXP) ( )}

c. One year or less ( )

d. 5 years or less ( )

e. 10 years or less ( )

f. 15 years or less ( )

g. 20 years or less ( )

h. More than 20 years or less ( )

\section{Business Size (SIZE)}

\begin{tabular}{|c|c|}
\hline & Large (more than 500 employees) \\
\hline & Medium (between 100-500 employees) \\
\hline & Small (less than 100 employees) \\
\hline & Missing \\
\hline
\end{tabular}

Study Concepts and Items

1- International marketing strategies (IMS)

1. Our firm modifies existing products to a great extent (IMS1)

2. Our firm emphasizes product quality and warranties (IMS2)

3. Our firm engages in development, testing and introduction of new products to a great extent (IMS3)

4. Our firm eliminates products that do not satisfy customer needs to a great extent (IMS4)

5. Our firm engages in analysis of competitors' prices to a great extent (IMS5)

6. Our firm frequently offers discounts (IMS6)

7.Our firm sets strategic promotional objectives (IMS7)

8. Our firm carefully develops advertising/promotion messages (IMS8)

9. Our firm provides after sales services (IMS9)

10. Our firm builds strong relationship with distributors (IMS10)

11. Our firm provides a lot of channel support (IMS11)

12. Our firm carefully evaluates alternative channels of distribution (IMS12)

13. Our firm engages in designing and implementing effective dealer relations programs (IMS13)

\section{2-Brand orientation (BO)}

1. Branding flows through all our marketing activities (BO1)

2. Branding is essential to our strategy (BO2)

3. Branding is essential in running this firm (BO3)

4. Long term brand planning is critical to our future success (BO4)

5. The brand is an important asset for us (BO5)

6. Everyone in this firm understands that branding our product/service is a top priority for our business (BO6)

\section{3-Financial performance (FP)}

1. Growth rate of sales in the overseas markets in the last 12 months (FP1)

2. Your market share in the overseas markets in the last 12 months (FP2)

3. Profitability of your firm in the overseas markets in the last 12 months (FP3)

4. Overall financial performance in the overseas markets in the last 12 months (FP4)

5. We are very satisfied with our sales performance in the overseas markets (FP5)

6. The total return on your investment (ROI) of the overseas market (FP6)

7. Overall, our firm has fully capitalized on the potential that overseas markets afford for our firm (FP7)

8. We are satisfied with the ratio of overseas to domestic sales (FP8)

9. We are satisfied with the sales profitability ratio from the overseas market (FP9)

\section{4-Brand performance (BP)}

1. Our overall marketing strategy is working well (BP1)

2. Our firm has built a strong brand awareness in the target market (BP2)

3. Our firm has built a solid brand reputation (BP3)

4. We are very satisfied with our brand marketing (BP4) 
5. Our firm has built strong customer brand loyalty (BP5)

\section{5-International commitment (ICOM)}

1. We have promised resources (e.g. information technology and human resources) to the international ventures (ICOM 1)

2. The extent of management commitment to the international marketing venture is substantial (ICOM2)

3. Our firm sets aside adequate funds to develop overseas markets (ICOM3)

4. Our firm's executives travel frequently to foreign markets (ICOM4)

5. International business is a high priority activity in our company (ICOM5)

\section{6-Brand repositioning (BR)}

1. Compared to the domestic market, the quality of the product in the foreign market was increased (BR1)

2. Compared to the domestic market, the target market of the brand in the foreign market was moved upmarket (BR2)

3. Compared to the domestic market, the approach of promotion/advertising in the foreign market was different (BR3)

4. Compared to the domestic market, the product features in the foreign market were different (BR4)

5. Compared to the domestic market, the distinctive identity of the brand in the foreign market was different (BR5)

6. Compared to the domestic market, the distribution of the brand in the foreign market requires a different method of distribution/outlet (BR6)

\section{7-Congruence of marketing environment (CUE)}

1. In relation to the domestic market, the foreign market is more unstable (CUE1)

2. In relation to the domestic market, customers in this foreign market behave differently (CUE2)

3. In relation to the domestic market, disposable income of this foreign market is lower (CUE3)

4. In relation to the domestic market, customers in this foreign market are wealthier (CUE4)

5. In relation to the domestic market, the motivation of customers in the foreign market is harder to understand (CUE5)

6. In relation to the domestic market, people in this foreign market tend to value individual time more (CUE6)

7. In relation to the domestic market, interpersonal relationships in this foreign market are more important (CUE7)

8. In relation to the domestic market, the technological knowledge of customers in this foreign market is more sophisticated (CUE8)

9. In relation to the domestic market, visual aspects such as packaging and colours are more important in this foreign market (CUE9)

10. In relation to the domestic market, the distribution system in this foreign market is more complex (CUE10)

11. In relation to the domestic market, the culture in this foreign market is totally different (CUE11)

\section{8-Control of international branding activities (CIBA)}

1. Our firm wanted to have a considerable influence over the marketing of the products/services

\section{(CIBA1)}

2. Our firm wanted to control major decision-making of the foreign operation (CIBA2)

3. Our firm wanted to make the decisions relating to the integrity of the brand (CIBA3)

Notes:

(1) Strongly Disagree, (2), Disagree, Don't Know (3), Agree (4), Strongly Agree (5).

\section{Copyrights}

Copyright for this article is retained by the author(s), with first publication rights granted to the journal.

This is an open-access article distributed under the terms and conditions of the Creative Commons Attribution license (http://creativecommons.org/licenses/by/4.0/). 